\title{
บusisersaly
}

\section{Book review: Mainstreaming the Headscarf: Islamist Politics and Women in the Turkish Media}

Akser, M. (2020). Book review: Mainstreaming the Headscarf: Islamist Politics and Women in the Turkish Media. European Journal of Communication, 35(5), 528. https://doi.org/10.1177/0267323120952581

Link to publication record in Ulster University Research Portal

\author{
Published in: \\ European Journal of Communication
}

Publication Status:

Published (in print/issue): 01/10/2020

DOI:

$10.1177 / 0267323120952581$

\section{Document Version}

Author Accepted version

\section{General rights}

Copyright for the publications made accessible via Ulster University's Research Portal is retained by the author(s) and / or other copyright owners and it is a condition of accessing these publications that users recognise and abide by the legal requirements associated with these rights.

\section{Take down policy}

The Research Portal is Ulster University's institutional repository that provides access to Ulster's research outputs. Every effort has been made to ensure that content in the Research Portal does not infringe any person's rights, or applicable UK laws. If you discover content in the Research Portal that you believe breaches copyright or violates any law, please contact pure-support@ulster.ac.uk. 


\section{Esra Ozcan}

Mainstreaming the Headscarf: Islamist Politics and Women in the Turkish Media, I.B. Tauris: London, 2019; 280 pp.: £85. (hardcover).

ISBN: 9781788314015

\section{Reviewed by: Murat Akser, Ulster University, United Kingdom}

This is a timely book as Turkey's AKP under the leadership of president Tayyip Erdogan is about to reach two decades of increasingly authoritarian rule and conservative political transformation. As an expat feminist Turkish communications and media scholar working in the USA, Esra Ozcan, has experienced first-hand the headscarf ban of the 1990s in Turkish universities as a BA and MA student on which she later has based her graduate studies. As a young woman wearing headscarf herself, she has suffered discrimination through the repressive policies of the secularist Kemalist elite that held checks and balances through an unelected military-civilian bureaucratic elite that ruled the country until the early 2000s. In her book, Mainstreaming the Headscarf, Ozcan reflects on the symbolic use of headscarf through images in newspapers and how the conservative women newspaper columnists used it at first to bring attention to their marginalized/repressed status as women under an authoritarian system and later on how these same women broke their negotiation with liberal intellectuals and secular feminists and betrayed them by supporting the neo-con agenda of AKP and Erdogan.

Ozcan uses a qualitative method combining content analysis with discourse analysis to sample and comment on three conservative women columnists who have written on the headscarf issue since the late 1990s until 2015. Her main area of concentration is around key turning points in AKP's electoral history $(2002,2007,2011)$ as well as newspapers published around the time of major referendums plus the aftermath of July 15, 2016 coup attempt after when AKP won by a minor margin to change the checks and balances of the country's political system eventually leading to an authoritarian one-man presidential system.

The book is organised into six parts. The introduction lays down the foundations of her main argument where she claims that the term 'islamist feminist' is misleading and why she prefers to use the term right wing conservative women instead. Ozcan draws parallels with AKP's neo-conservative economic and social policies and draws parallels as to how women around the world are also pushed more and more to have insecure, underpaid, home worker jobs and how a misogynist discourse is defended by women newspaper columnists to legitimate mysoginyst discourses by authoritarian politicians.

The first chapter chronicles and problematises the secularism versus Islamism debate that led to AKP's rise to power in 2002. The chapter successfully narrates major events during AKP's time in power. Ozcan also describes and debates in detail the mechanism of media capture and repression that has happened since 2010 in Turkey and its implications for liberal and feminist voices. Chapter two tells the story of the headscarf ban from the perspectives of different parties in Turkey and exposes the common rhetorical strategies used to defend or oppose the headscarf. Here Ozcan uses examples from her own personal family history to discuss in length how the lives of successive generations of young women in Turkish universities have been effected by the headscarf ban and how such visuals of women in headscarf are used ideologically to support a right-wing gender regime to come under AKP's authoritarian rule. 
Chapter three is on visual culture of gender representation in Turkish newspapers. Here Ozcan is able to situate the debates around the headscarf issue thorough an analysis of visuals culture and news. Here she analyses news photographs in four newspapers in the political spectrum from secular to islamist published between 2002-2012. The analysis results in important findings: that stories of poor women in headscarf (images of poverty) are replaced by successful middle-class women in AKP's ranks (headscarf and SUVs) and female columnists wearing the headscarf moved from margins to centre and moved from being the critics of establishment to defenders of the new establishment.

Chapter four is a thorough analysis of three key right-wing conservative women journalists' columns. Ozcan draws particular attention to the argumentative strategies used by these women to justify AKP's and Erdogan's authoritarianism. She illustrates in detail how conservative women journalists' approached controversial topics and events that helped deepen polarisation in Turkish society such as Occupy Gezi Park protests (May 2013), the now defunct peace process with the Kurds, and the restriction on alcoholic beverage consumption. Particular attention is paid to these conservative women's break with Turkey's liberal democrats as part of a hegemonic struggle to gain the power to define what constitutes as 'common sense'. Ozcan discusses in detail this process of conservative women becoming part of the new establishment and visual/rhetorical strategies they used in their columns to legitimate AKP's conservative gender vision and other authoritarian social policies.

In Chapter five, Ozcan lays out an interpretation of how left wing and progressive feminist movements in Turkey interact with the conservative women in a highly polarised political climate where feminists are constantly demonised by AKP and Erdogan. She points at the possible dilemmas faced by Turkish feminists to distance themselves from religious doctrines that limit women's freedoms but also oppose islamophobia. She proposes the questions as to who has the power and right to represent 'women's rights' and points at the conflicting perspectives in AKP's gender policies. The chapter is successful in linking this debate to the broader questions within feminism. Ozcan also proposes the critical wing of conservative women as the possible new allies of leftist feminists against rising competitive authoritarianism in Turkey.

In chapter six, the conclusion, Ozcan discusses the potential for a new gender equilibrium under the AKP regime in Turkey. She sums up the findings and debates raised in the book and points at different possible directions of the headscarf debate in Turkey for the future. This chapter has Gramscian overtones as Ozcan uses Gramsci's concepts to propose new analytical possibilities to push back and claim new domain from AKP's ideological realm. She is also wary of the growing disconnect between intellectuals like herself and half of the country's population that seem not care how the other half lives. She is right to be concerned as the most recent authoritarian developments such as the complete closure of bars serving alcohol during covid crisis, attacks on LGBT rights supporters, laws passed to limit social networks and ban Netflix in practice for showing undesirable gender roles all point at the dangers for people with secular lifestyles under AKP's authoritarian rule.

Mainstreaming the Headscarf has three unique contributions: First it shows how an everyday use of an ordinary object like headscarf can be used as a changing symbol depending on the user's political status. Right wing conservative women used it to claim marginalized/repressed status, then used it again to form alliances with secular feminists and liberal intellectuals and finally they are using it as power status symbol under AKP's authorization regime. Ozcan illustrates well how a symbol like a headscarf can be used 
visually for ideological positioning by right wing conservative women journalists in Turkey who later came to become engineers of AKP's new gender hegemony which paved the way for the eventual authoritarianism of President Erdogan. Finally, the book proposes ways to break the new authoritarian gender hegemony of AKP and Erdogan by claiming new ground by pushing back and regaining the secular freedoms. Overall, Mainstreaming the Headscarf is a theoretically engaging book rich with in-depth examples and analyses on Turkish media and proposing news ways to break right wing conservative hegemonic media rule by authoritarian governments. Ozcan does this by carefully avoiding binaries like secular versus islamist in her discussion throughout the book. It is a rich book which advocates new methods to counter hate media by AKP government through first-hand personal insights and anecdotes while making theoretically rich propositions. 